\title{
Modern Technogenic Geodynamics of Platform Territories by Example of Southern Cis-Urals
}

\author{
Tsviak A.V. \\ Department of geoecology \\ Orenburg Scientific Center of the Ural Branch of the \\ Russian Academy of Sciences \\ Orenburg, Russia \\ e-mail tsviak@rambler.ru
}

\author{
Nesterenko M.Yu. \\ Department of geoecology \\ Orenburg Scientific Center of the Ural Branch of the \\ Russian Academy of Sciences \\ Orenburg, Russia \\ e-mail n_mu@mail.ru
}

\author{
Nesterenko A.M. \\ Department of geoecology \\ Orenburg Scientific Center of the Ural Branch \\ of the Russian Academy of Sciences \\ Orenburg, Russia \\ e-mail alexnes@mail.ru
}

\begin{abstract}
This paper presents geodynamics of the Southern Cis-Urals region. It focuses on seismicity induced by hydrocarbon production by summarizing the published case studies. Natural and man-made changes in bowels of the Earth are usually accompanied by tectonic movements and deformations of earth's surface, which is one of the important factors determining environmental changes and requiring mandatory consideration in engineering-geological surveys and exploitation of deposits. The influence of anthropogenic factors on the geodynamic state of platform areas is considered by the example of Orenburg oil and gas condensate field and Baitugan oil field.
\end{abstract}

Keywords - Induced seismicity, hydrocarbon fields, seismic hazard, monitoring, midcrustal earthquakes

\section{INTRODUCTION}

Geodynamics of the Southern Cis-Urals region are poorly understood, since the region is located inside the platform, and platform territories are considered to be geodynamically lowactive and low-seismic. Until recently, it was believed that earthquakes rarely appear on the earth's surface by shocks of up to 4-5 Richter scale, and most of the oscillations recorded on the platform are only echoes of strong earthquakes from seismically active regions. The greatest attention was paid to areas with active mountain-folded structures. However, at present, it has become clear that the intra-platform territories are also mobile, especially in areas of tectonic disturbances and near folded areas. Confirmation of this fact is a large number of earthquakes recorded on the platforms, for example, in 1976 on the South China Platform with $M=7.8$ magnitude [4]; in 2004 in Kaliningrad region - 6 Richter scale; in 2008 in the north of Kazakhstan at a distance of 150 $\mathrm{km}$ to the south of the city of Orenburg near the lake Shalkar with $\mathrm{M}=5.3$ magnitude. In the Republic of Tatarstan two focal zones were identified in the areas of Elabugi town and Almetyevsk town, where earthquakes of 5-6 Richter scale were recorded [1]. In our opinion, the natural seismic activity is caused by movements of blocks of the earth's crust relative to each other. The block structure of the basement and sedimentary cover is discovered by geological and geophysical studies [1]. We believe that natural seismicity is connected with the latter. In addition to natural seismicity and geodynamic activity, technogenic geodynamics are becoming a significant factor, the value of which increases as the intensity of oil and gas production in exploited fields increases. Technogenic seismicity receives discharge mainly through existing mobile zones. Analysis of tasks and results of geoecological studies [3, 5-10] shows that the main anthropogenic impact on lithosphere during oil and gas production is due to extraction of large volumes of substance, drop of formation pressure and appearance of uncompensated stresses in Earth's crust. These stresses reach 1000 tons or more per square meter. Such stresses lead to formation of technogenic geodynamic processes and block movements of the earth's crust. They can provoke a discharge of accumulated natural stresses and can cause earthquakes and destruction. Such earthquakes and block movements of earth's crust have already occurred and now occur in some oil and gas fields, for example, in the Romashkinskoe oil field in Tatarstan, in large fields in Siberia, in the largest gas field in Europe Groningen, etc. In the western part of Orenburg region, which belongs to South Cis-Urals, more than 120 oil and gas fields are being developed, so that the areas of man-made changes that occur during their development intersect. It provokes emergence of many environmental problems that have a negative impact on development of nature and livelihoods of the population in the region. Natural and man-made changes in bowels of the Earth are usually accompanied by tectonic movements and deformations of earth's surface, which is one of the important factors determining environmental changes and requiring mandatory consideration in engineeringgeological surveys and exploitation of deposits. The influence of anthropogenic factors on the geodynamic state of platform 
areas is considered by the example of Orenburg oil and gas condensate field (OOGCF) and Baitugan oil field.

\section{METHODS}

We adopt a complex approach to the basis of monitoring methodology of a geodynamic state of the region under study with conditions of anthropogenic impact. The approach takes into account mutual influence of geological structures, dynamics of a hydro geosystem, mining and the stress-strain state of the environment.

The task is solved first by setting up seismic stations and recording seismic signals for 3-5 years, while constructing geodynamic observations. Then, we integrate data on a seismic activity of the region until the accumulated density of released seismic energy from man-made events is reached and set a threshold value of released seismic energy of $107 \mathrm{~J}$ per $100 \mathrm{~km} 2$ (seismic events with a magnitude of more than 3 must be recorded). After it we regionalize the territory according to the level of geodynamic activity, pick out the areas with abnormally high geodynamic activity. And if anomalously high seismic activity is detected, let us compact the seismological network in areas with anomalously high geodynamic activity by adding at least two seismic stations to each of the seismically active geological structures of the identified field, and earth strains are monitored surfaces on geodynamically active sites.

With the usage of 3D seismic survey materials, conducted by AO "Samaraneftegeofizika" in 2008-2009, we detailed and clarified a tectonic scheme of the Baitugan field.

\section{RESULTS}

The analysis of seismic activity distribution of a subsoil shows that the main portion of seismic events is located in areas of intensively developed hydrocarbon deposits (Table 1). The territories far from zones with technogenic disturbances (Central and Eastern parts of the Pre-Ural regional deflection, the Southeast of Caspian syneclise and others) have a much lower frequency of seismic events and, probably, they are caused by natural tectonic processes. The events that occur in the areas of technogenic disturbances of a geological environment occur more often and have more complex origins and they apparently should be attributed to man-made or natural-man-made.

A complex tectonic structure of the territory, high density of fractures in an area of development, modern tectonic movements necessitate the observation that must be enough for a normal technological cycle of works and predicting of dangerous situations.

Currently, in accordance with design solutions for monitoring the development of dynamic processes on the territory of the field, three seismic stations and the rapper system based on field's core surveying network are established.

For the period from 2015 to August 2017, a specified network of seismic stations registered 10 seismic events and 32 pulsed seismic events in the field. Moreover, the pulses occur in the immediate vicinity of the recording station and, as a rule, are of technogenic character (Fig. 1).

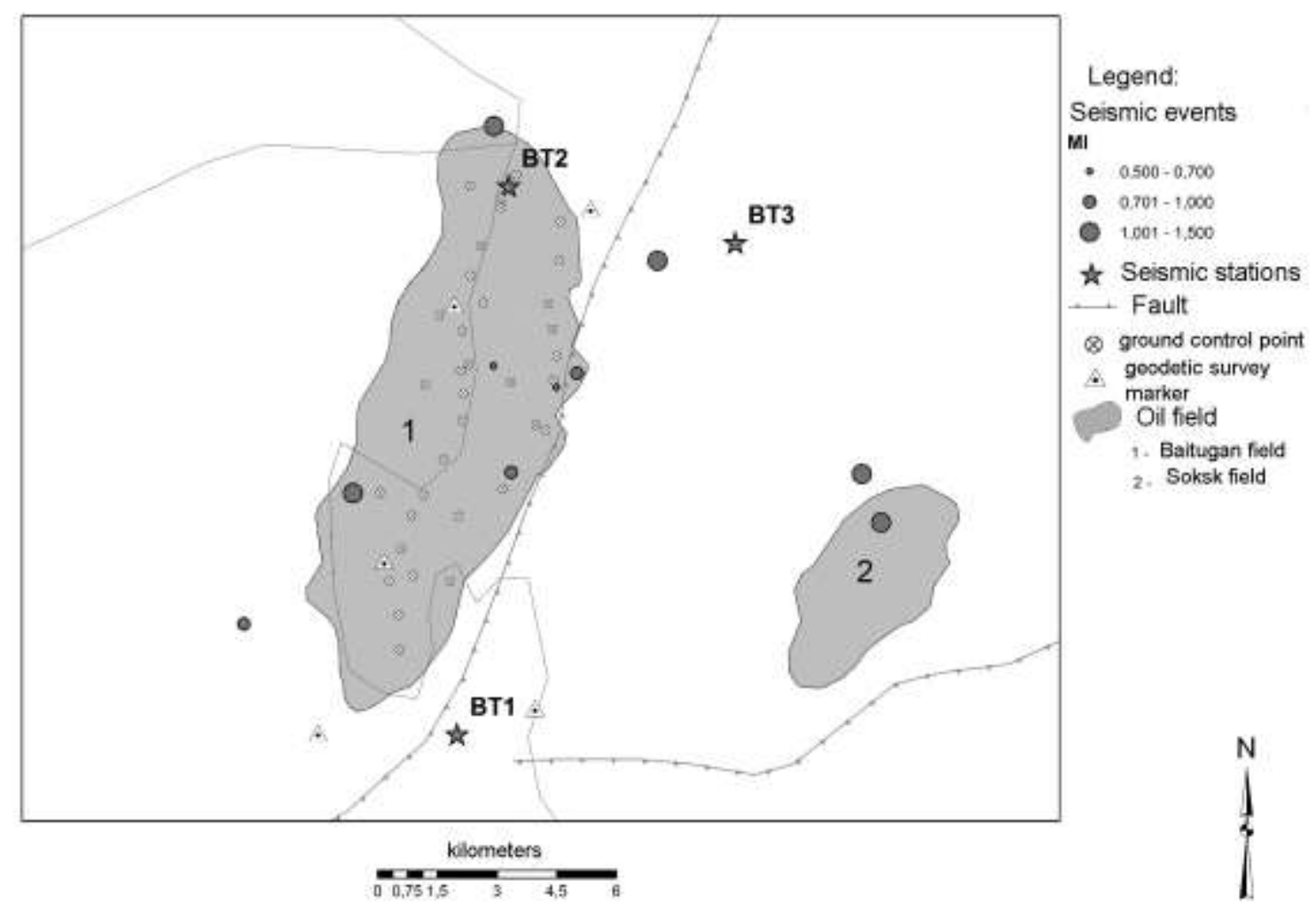

Fig 1. Scheme of structure-forming faults, oil and gas fields and epicenters of seismic events in the northwestern part of the Orenburg region from 2015 to 2017 
The number of seismic events recorded within the field is many times greater than the natural seismicity of the territories adjacent to the field. At the same time, in the first approximation, one can note seismic events in the contour of the Baitugan field approach to the Baitugan meridian fault. Thus, with a fair degree of certainty, it can be argued that epicenters of the seismic events approach to stress-deformed nodes of the block-fracture system of the Baituganskoye field, which experiences the effects of prolonged natural and manmade factors.

During the study of seismic activity factors on the territory of the Orenburg oil and gas condensate field, we set the task of identifying the seismic process stages (long-term forecast). Another task is searching for areas of the increased stress gradient and assessing the seismic hazard of the region in connection with the development of hydrocarbon deposits. A detailed analysis of dependence of seismic events on a geological structure will be continued after creating a reliable cartographic basis for fault structures, ranking faults, a sufficient statistical sample of seismic events. It will allow estimating of stress concentration zones and classifying the earth's crust areas by geodynamic hazard.

Table 1 provides information on the number of recorded events, the epicenters of which fall into the contour and in the strip zones around the deposits at different distances from them. It was revealed that in contours of oil and gas fields the density of events averages 0.0027 units $/ \mathrm{km} 2$ per year. In the strip zone limited by distances up to $10 \mathrm{~km}$ from the field, it decreases by $44 \%$ to 0.0015 . Outside of $10 \mathrm{~km}$ from deposits, the number of events decreases 3-4 times compared with their number in the contour of deposits with a density of 0.0008 units $/ \mathrm{km} 2$ per year. Consequently, $1.6 \%$ of a territory in the contour of fields and $10 \mathrm{~km}$ around them have more than $35 \%$ of all events in a general territory of the Southern Ural region controlled by seismic monitoring.

TABLE 1. DENSITY OF RECORDED EVENTS AND RELEASED SEISMIC ENERGY IN THE AREA OF HYDROCARBON DEPOSITS

\begin{tabular}{|l|l|l|l|l|l|l|}
\hline & & & & & \\
\end{tabular}

TABLE 2. DENSITY OF RECORDED EVENTS AND RELEASED SEISMIC ENERGY IN THE OOGCF AREA AND ADJACENT TERRITORIES

\begin{tabular}{|c|c|c|c|c|c|c|}
\hline 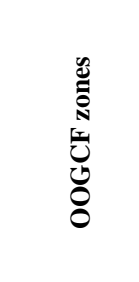 & $\frac{\text { है }}{\text { है }}$ & 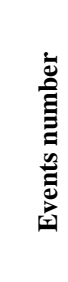 & 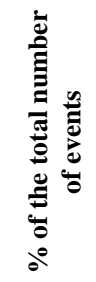 & 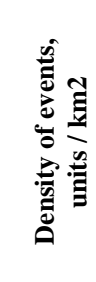 & 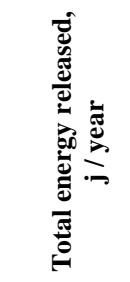 & 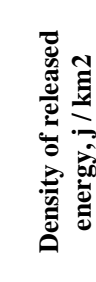 \\
\hline $\begin{array}{l}\text { In the field } \\
\text { contour }\end{array}$ & 1695 & 5.0 & 8.67 & 0.0029 & $0.92 * 1010$ & $\begin{array}{l}0.54 * 10 \\
7\end{array}$ \\
\hline $\begin{array}{l}5 \\
\text { around }\end{array}$ & 2687 & 7.3 & 12.72 & 0.0027 & $1.87 * 1010$ & $\begin{array}{l}0.69 * 10 \\
7\end{array}$ \\
\hline $\begin{array}{l}\text { Orenburg } \\
\text { Cis-Urals } \\
\text { region }\end{array}$ & 661706 & 57.7 & 100 & 0.0008 & $7.56 * 1010$ & $\begin{array}{l}0.11 * 10 \\
6\end{array}$ \\
\hline
\end{tabular}

TABLE 3. DENSITY OF RECORDED EVENTS AND RELEASED SEISMIC ENERGY IN THE HYDRODYNAMIC FUNNEL ZONE AT OOGCF

\begin{tabular}{|c|c|c|c|c|c|c|}
\hline Zones & 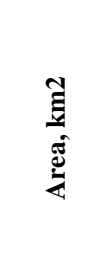 & 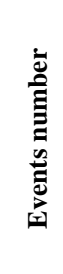 & 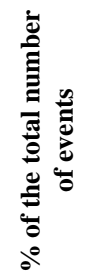 & 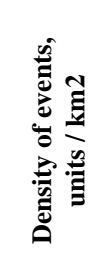 & 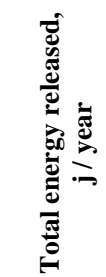 & 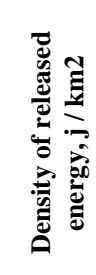 \\
\hline $\begin{array}{l}\text { Hydrodynami } \\
\text { c funnel }\end{array}$ & 1645.9 & 8.3 & 14.45 & 0.005 & $\begin{array}{l}1.98 * 10 \\
10\end{array}$ & $\begin{array}{l}1.20 * 1 \\
07\end{array}$ \\
\hline $\begin{array}{l}5 \mathrm{~km} \text { around } \\
\text { the funnel }\end{array}$ & 2451.2 & 9.3 & 16.18 & 0.0038 & $\begin{array}{l}2.05 * 10 \\
10\end{array}$ & $\begin{array}{l}0.83 * 1 \\
07\end{array}$ \\
\hline $\begin{array}{l}\text { Orenburg Cis- } \\
\text { Urals region }\end{array}$ & $\begin{array}{l}66170 \\
6\end{array}$ & 57.7 & 100 & 0.0008 & $\begin{array}{l}7.56 * 10 \\
10\end{array}$ & $\begin{array}{l}0.11 * 1 \\
06\end{array}$ \\
\hline
\end{tabular}

The analysis of tables 2 and 3 shows that in the area of Orenburg oil and gas condensate field, most of the released energy and seismic events occur in the area of the hydrodynamic funnel. Within the hydrodynamic funnel, density of recorded events is 5-6 times greater, and the released energy is 10 times greater than the average in the South Cis-Urals region.

\section{CONCLUSION}

Thus, the results of layer-by-layer overlapping schemes of tectonic elements of the research area, topography, river network, seismic events and the extent of planetary tectonic fracture zones, as well as the results of the analysis of the density of recorded events, allow us to draw the following conclusions with sufficient confidence:

1. Concentration of seismic events in the first approximation is consistent with technologically disturbed blocks of rock massifs (oil and gas fields).

2. Epicenters of seismic events approach zones of fault structures. This, in turn, makes it possible to consider fault zones as a natural factor of seismic activity in the Southern Cis-Urals. 
3. The study of natural and man-made seismicity makes it possible to specify the geological structure of the upper part of the earth's crust, in particular, the position of fault structures.

\section{References}

[1] V.V. Adushkin, V.N. Rodionov, S. Turuntaev, A.E. Yudin, "Seismicity in the oil field," Oilfield Rev., vol. 12(2), pp. 2-17, January 2000.

[2] D. Amorese, J.R. Grasso, L.M. Plotnikova, B.S. Nurtaev, R. Bossu, "Rupture kinematics of the 'three gazli major earthquakes from vertical and horizontal displacement data", Bull. Seism. Soc. Am. 85 (2), pp. 552-559, April 1995.

[3] M.R. Baker, D.I. Doser, M. Luo, "Geologic and oil field controls on earthquakes in the War-Wink Field, Delaware Basin”, Bulletin - West Texas Geol. Soc. 31(1), 5-12, January 1991.

[4] R. Butler, S.G. Stewart, H. Kanamori, "The July 27, 1976 Tangshan, China earthquake-A complex sequence of intraplate events", Bulletin of the Seismological Society of America, Vol. 69, No. 1, pp. 207-220, February 1979.
[5] J.F. Gibbs, J.H. Healy, C.B. Raleigh, J. Coakley, "Seismicity in the Rangely, Colorado, Area:1962-1970”, Bull. Seism. Soc. Am. 63 (5), pp. 1557-1570, May 1973.

[6] S.J. Gibowicz, S. Lasocki, "Seismicity induced by mining: Ten years later," Adv. Geophys. 44, pp. 39-180, December 2001.

[7] D.G. Evans, D.W. Steeples, "Microearthquakes near the Sleepy Hollow oil-field, Southwestern Nebraska", Bull. Seism. Soc. Am. 77 (1), pp. 132-140, January 1987.

[8] J. Suckale, "Induced seismicity in hydrocarbon fields", Adv Geophys 51, pp. 55-106, December 2009.

[9] S.B. Turuntaev, O.A. Razumnaya, "An application on induced seismicity data analysis for detection of spatial structures and temporal regimes of deformation processes in hydrocarbon fields", Pure Appl. Geophys, vol. 159 (1-3), pp. 421-447, January 2002.

[10] Van Eijs, R.M.H.E., Mulders, F.M.M., M. Nepveu, C.J. Kenter, B.C. Scheffers, "Correlation between hydrocarbon reservoir properties and induced seismicity in the Netherlands", Eng. Geol., vol. 84 (3-4), pp 99-111, May 2006. 